\title{
WASTE MATERIAL BETON PADA PROYEK KONSTRUKSI DI JAKARTA
}

\author{
Kevin Liman ${ }^{1}$ dan Hendrik Sulistio ${ }^{2}$ \\ ${ }^{1}$ Program Studi Sarjana Teknik Sipil, Universitas Tarumanagara, Jl. Letjen S. Parman No.1 Jakarta \\ kevin.3251501016@stu.untar.ac.id \\ ${ }^{2}$ Program Studi Sarjana Teknik Sipil, Universitas Tarumanagara, Jl. Letjen S. Parman No.1 Jakarta \\ Hendriks@ft.untar.ac.id
}

Masuk: 17-01-2020, revisi: 17-02-2020, diterima untuk diterbitkan: 19-02-2020

\begin{abstract}
Waste material can be interpreted as undesirable or valueless material for ordinary or primary purposes in the manufacture or use. This study aims to determine how much the remaining material that occurs in concrete construction work and the form of handling carried out to prevent material waste. The purpose of this study was to determine how much material waste occurred, losses caused by material waste and to find out the cause of material waste. The research sample taken was a low rise building project in Jakarta and its surroundings. The method used in data collection is field observations and interviews. Data obtained in the form of Bill of Quantity, working drawings, or monthly reports. Data analysis using quantitative analysis to determine the largest type of material and losses in concrete work calculated by the regression method assisted by the SPSS program to get the large losses that occur in concrete construction work. The results obtained are the largest residual construction material in concrete construction is $7.05 \%$ for low rise building projects in Jakarta and surrounding areas and losses (\%) that have a regression such as the following $Y=-1.640+0.669 X 1+0.481 X 2+0.098 X 3$.
\end{abstract}

Keywords: waste Material, Waste management and concrete

\begin{abstract}
ABSTRAK
Waste material dapat diartikan sebagai material yang tidak diinginkan atau tidak berharga untuk maksud biasa atau utama dalam pembuatan atau pemakaian. Penelitian ini bertujuan untuk mengetahui seberapa besar sisa material yang terjadi pada pekerjaan konstruksi beton dan bentuk penanganan yang dilakukan untuk mencegah terjadinya waste material. Tujuan penelitian ini untuk mengetahui seberapa besar waste material yang terjadi, kerugian yang ditimbulkan oleh waste material tersebut dan mengetahui penyebab terjadinya waste material tersebut. Sampel penelitian ini diambil adalah proyek low rise building yang ada dijakarta dan sekitarnya. Metode yang digunakan dalam pengumpulan data adalah dengan cara pengamatan lapangan dan wawancara. Data yang diperoleh berupa Bill of Quantity, gambar kerja, atau laporan bulanan. Analisis data menggunakan analisis kuantitaf untuk mengetahui jenis material yang terbesar dan kerugian dalam pekerjaan beton dihitung dengan metode regresi dibantu dengan program SPSS untuk mendapatkan besar kerugian yang terjadi pada konstruksi pekerjaan beton. Hasil yang diperoleh adalah sisa material konstruksi terbesar pada kontruksi beton adalah $7.05 \%$ untuk proyek low rise building di Jakarta dan sekitarnya dan kerugian (\%) yang memilik regresi seperti berikut $\mathrm{Y}=-1.640+0.669 \mathrm{X} 1+0.481 \mathrm{X} 2+$ $0.098 \times 3$.
\end{abstract}

Kata Kunci: Sisa Material, Waste management dan beton

\section{PENDAHULUAN}

Perkembangan bidang konstruksi di era modern ini telah mengalami perkembangan yang pesat. Hal ini dapat dilihat dari pembangun jalanan, jembatan, perumahan, gedung bertingkat seperti apartemen, perkantoran, pusat perbelanjaan, maupun bangunan-bangunan lainnya.

Dalam proses konstruksi material memiliki peranan penting. Suatu proses konstruksi membutuhkan material bangunan baik itu bahan utama maupun bahan pembantunya, sehingga penggunaan material dalam suatu proses konstruksi sangat penting dalam kelangsungan pelaksanaan konstruksi.

Pada proyek konstruksi, material dapat menimbulkan berbagai masalah yang tidak dapat terhindar seperti Waste material dalam proyek tersebut. Waste material konstruksi didefinisikan sebagai sesuatu yang sifatnya berlebih dari 
yang disyaratkan baik itu berupa hasil pekerjaan maupun material konstruksi yang tersisa, tercecer atau rusak sehingga tidak dapat digunakan lagi sesuai fungsinya (J.R. Illingworth, 1998).

Namun secara tidak disadari oleh banyak orang, penggunaan dan pengelolaan material ini kurang diperhatikan maka sering terjadi pemborosan baik pada penggunaan material yang berlebihan. Banyak faktor yang menjadi sumber terjadinya sisa material konstruksi, antara lain desain, pengadaan material, penanganan material, pelaksanaan, residul dan lain-lain (Gavilan dan Bemold, 1994).

Salah satu material yang berkonstribusi menghasilkan waste material adalah beton (Bossink dan Browers, 1996). Beton ini digunakan dalam proses konstruksi bangunan. Beton terdiri dari berbagai material lainnya seperti semen, pasir (agregat halus), kerikil (agregat kasar), dan air (PBI 1971). Pembuatan beton pada proses konstruksi seringkali kurang diperhatikan sehingga terjadi waste material di lokasi proyek.

Oleh karena itu sangatlah dibutuhkan pemahaman tentang penanganan waste yang terjadi pada material beton yang meliputi berbagai jenis waste yang ditumbulkan pada proses konstruksi serta faktor-faktor yang menyebabkan waste material tersebut. Untuk masa yang akan mendatang, maka pengetahuan untuk menanggulangi waste material sangat dibutuhkan untuk mengurangi waste material yang ditimbulkan pada proses konstruksi.

Waste material adalah material yang tidak diinginkan atau tidak berharga untuk maksud biasa atau utama dalam pembuatan atau pemakaian. Waste di bidang konstruksi dapat diartikan sebagai kehilangan atau kehilangan sumber daya material, waktu (berkaitan dengan tenaga kerja dan peralatan) dan modal, yang disebabkan oleh kegiatan yang membutuhkan biaya, langsung atau tidak langsung, tetapi tidak menambah nilai pada akhir produk untuk pengguna jasa konstruksi (Waty et al, 2018) Environmental Protection Act (1990) Pasal 75 mendefinisikan limbah sebagai berikut :

1. Substansi yang tidak terpakai atau kotoran atau suatu kelebihan yang tidak diinginkan yang muncul dari aplikasi suatu proses.

2. Substansi atau benda yang cenderung akan patah, mencemarkan atau kerusakan lainnya namun tidak termasuk benda yang mudah meledak.

3. Apapun yang dibuang atau jika tidak diurus, yang berpotensi menjadi limbah kecuali jika masih dapat dimanfaatkan.diurus, yang berpotensi menjadi limbah kecuali jika masih dapat dimanfaatkan.

Menurut Skoyles (1987), sisa material konstruksi secara umum dikategorikan dalam 4 jenis, yaitu

1. Sisa Material Alami (Natural Waste)

Sisa material alami adalah sisa material yang dalam pembentukannya tidak dapat dihindarkan, misalnya pemotongan kayu atau penyambungan atau cat yang menempel pada kalengnya saat pengecetan. Sisa material ini terbentuk secara alami dalam batas toleransi. Namun ada kalanya sisa material alami ini menimbulkan sisa material langsung yang cukup besar jika tidak dilakukan pengontrolan yang baik, misalnya pada waktu pembuatan spesi, penuangan semen kadang tercecer ke tanah, jika tidak dilakukan pengontrolan maka ceceran semen menjadi banyak.

2. Sisa Material Langsung.

Sisa material langsung adalah sisa material yang terjadi pada setiap pembangunan. Biasanya sisa material ini terbentuk pada saat penyimpanan, pada saat material dipindahkan ke tempat kerja, atau pada saat proses pengerjaan tahapan pembangunan itu sendiri. Bila tidak dilakukan kontrol yang baik, sisa material ini akan menyebabkan kerugian yang cukup besar terutama dari segi biaya. Beberapa kategori sisa material langsung adalah akibat kegiatan sebagai berikut :

a) Sisa material akibat adanya kegiatan pengiriman, yaitu kehilangan pada saat pengiriman ke lokasi, penurunan barang dan saat penempatan ke gudang. Atau pada waktu pengangkutan yang tidak efektif sehingga kualitas barang menurun, dan barang tidak terpakai akhirnya menjadi sisa material.

b) Penyimpanan di gudang dan penyimpanan sementara di sekitar bangunan adalah sisa material yang disebabkan oleh penyimpanan yang buruk.

c) Sisa material akibat proses perubahan bentuk material, adalah sisa material yang disebabkan oleh proses perubahan bentuk material dari aslinya.

d) Sisa material selama proses perbaikan, adalah sisa material yang dihasilkan selama proses perbaikan.

e) Sisa material selama proses perbaikan, adalah sisa material yang dihasilkan dari material kalengan, seperti cat dan bahan plester yang tersisa pada tempatnya dan tidak digunakan.

f) Penggunaan lahan yang tidak efektif, adalah lahan yang tidak digunakan secara optimal, sehingga menyebabkan tidak efisien. Manajemen yang kurang baik.

g) Sisa material akibat penggunaan yang salah.

h) Sisa material akibat spesifikasi material yang salah.

i) Sisa material yang ditimbulkan akibat kurang terampilnya pakerja. 
3. Sisa Material Tidak Langsung.

4. Sisa Material Konsekuensi (consequential waste). yaitu:

Waste yang timbul dalam pelaksaan konstruksi dapat dikategorikan menjadi dua bagian (Intan, 2005),

1. Demolition waste adalah sisa material yang timbul dari hasil pembongkaran proses renovasi atau penghancuran bangunan lama.

2. Construction waste adalah sisa material konstruksi yang berasal dari proses pembangunan atau renovasi bangunan. Sisa material tersebut tidak dapat dipakai lagi sesuai dengan fungsi semula. Sisa material ini bisa terdiri dari beton, batu bata, plesteran, kayu, pipa dan lain-lain.

Construction waste dapat digolongkan kedalam dua kategori berdasarkan tipenya (Intan, 2005) yaitu:

1. Direct waste adalah sisa material yang timbul diproyek karena rusak dan tidak digunakan lagi, yang terdiri dari:

a) Transport \& Delivery Waste

Semua sisa yang terjadi pada saat melakukan transportasi material di dalam lokasi pekerjaan, termasuk pembongkaran dan penempatan pada tempat penyimpanan seperti membuang/ melempar semen, keramik pada saat dipindahkan.

b) Site Storage Waste

Sisa material yang terjadi karena penumpukan/ penyimpanan material pada tempat yang tidak aman terutama untuk material pasir dan batu

pecah, atau pada tempat dalam kondisi yang lembab terutama untuk material semen.

c) Conversion Waste

Sisa material yang terjadi karena pemotongan bahan dengan bentuk yang tidak ekonomis seperti material besi, beton, keramik, dan sebagainya.

d) Fixing Waste

Material yang tercecer, rusak atau terbuang selama pemakaian dilapangan seperti pasir, semen, batu bata, dan sebagainya.

e) Cutting Waste

Sisa material yang dihasilkan karena pemotongan bahan seperti, tiang pancang, besi beton, batu bata, keramik, besi beton, dan sebagainya.

f) Application \&Residu Waste

Sisa meterial yang terjadi seperti mortal yang jatuh.tercecer pada saat pelaksanaan atau mortar yang tertinggal dan telah mengeras pada akhir pekerjaan.

g) Criminal Waste

Sisa material yang terjadi karena pencurian atau tindakan perusakan (vandalism) di lokasi proyek.

h) Wrong Use Waste

Pemakaian tipe atau kualitas material yang tidak sesuai dengan spesifikasi dalam kontrak, maka pihak direksi akan memerintah kontraktor untuk menggantikan material tersebut yang sesuai dengan kontrak, sehingga menyebabkan terjadinya sisa material di lapangan.

i) Management Waste

Terjadinya sisa material disebabkan karena pengambilan keputusan yang salah atau keragu-raguan dalam mengambil keputusan, hal ini terjadi karena organisasi proyek yang lemah, atau kurangnya pengawasan.

2. Indirect waste adalah limbah material yang terjadi di proyek karena volume pemakaian volume melebihi volume yang direncanakan, sehingga tidak terjadi limbah material secara fisik di lapangan dan mempengaruhi biaya secara tersembunyi, contohnya ketebalan plesteran melebihi ketebalan atau volume yang direncanakan yang disebabkan oleh terjadinya deviasi dimensi elemen struktur pada saat pengecoran.

a) Substitution Waste

Sisa material yang terjadi karena penggunaannya menyimpang dari tujuan semula, sehingga menyebabkan terjadinya kehilangan biaya yang dapat disebabkan karena tiga alasan yaitu terlalu banyak material yang dibeli, material yang rusak, dan makin bertambahnya kebutuhan material tertentu.

b) Production Waste

Sisa material yang disebabkan karena pemakaian material yang berlebihan dan kontraktor tidak berhak mengklaim atas kelebihan volume tersebut karena dasar pembayaran berdasarkan volume kontrak, contoh pasangan dinding bata tidak rata.

c) Negligence Waste

Sisa material yang terjadi karena dilokasi (site error), sehingga kontraktor menggunakan material lebih dari yang ditentukan, misalnya: penggalian pondasi yang terlalu lebar atau dalam yang disebabkan karena 
kesalahan/kecerobohan pekerja, sehingga mengakibatkan kelebihan pemakaian volume beton pada waktu pengecoran pondasi.

\section{METODE PENELITIAN}

Penelitian ini dilakukan di kota Jakarta dan sekitarnya, dengan mengambil sampel 10 proyek low rise building. Penelitian diawali dengan pengumpulan data melalui pengamatan di lapangan, wawancara. Data yang diperlukan antara lain harga material, gambar proyek, Bill Of Quantity. Selanjutnya dilakukan analisis kuantitaf data untuk mendapatkan kuanitatas sisa material konstruksi secara nyata dilapangan. Sia material ini diperoleh dari perhitungan volume material siap pakai di lapangan dikurangin dengan volume material desain berdsarkan gambar rencana proyek dan Bill Of Quantity., kemudian dikurangi dengan material sisa dilapangan.

Selanjutnya perhitungan menggunakan regresi linier dibantu dengan program SPSS untuk menghitung seberapa besar kerugian yang terjadi pada konstruksi pekerjaan beton dengan variable independent kerugian (\%) dan variable dependen jenis material semen, kerikil, dan pasir.

\section{HASIL DAN PEMBAHASAN}

\section{Menentukan besar persentase sisa material}

Untuk menentukan sisa material maka dibutuhkan kebutuhan material dan material pesanan dari data berdasarkan gambar rencana proyek atau Bill of Quantity. Kebutuhan material dan material pesanan dapat dilihat pada tabel 1 dan tabel 2 .

Tabel 1 Kebutuhan material

\begin{tabular}{cccc}
\hline Nama Proyek & \multicolumn{2}{c}{ Kebutuhan Material } \\
& $\begin{array}{c}\text { Semen } \\
(\text { sak })\end{array}$ & $\begin{array}{c}\text { Pasir } \\
\left(\mathrm{m}^{3}\right)\end{array}$ & $\begin{array}{c}\text { Kerikil } \\
\left(\mathrm{m}^{3}\right)\end{array}$ \\
\hline Proyek Town House Sinar Indah 1 & 736.01 & 72.26 & 109.73 \\
\hline Proyek Town House Sinar Indah 2 & 809.61 & 79.49 & 120.71 \\
\hline Proyek Town House Sinar Indah 3 & 1214.42 & 119.23 & 181.06 \\
\hline Proyek Rumah Cluster 2 lantai Type Azela & 892.60 & 47.98 & 55.98 \\
\hline Proyek Pembangunan Ruko Bintaro & 343.28 & 33.70 & 51.18 \\
\hline Proyek Ruko 3 lantai Karang Tengah & 484.37 & 47.56 & 72.22 \\
\hline Proyek Rumah tinggal 2 lantai Rekayon Indah & 764.11 & 32.50 & 37.90 \\
\hline Proyek Rumah tinggal 2 lantai Cisauk & 918.85 & 49.39 & 57.62 \\
\hline Proyek Pembanguna rumah tinggal 2 lantai Sunter & 761.25 & 39.20 & 45.77 \\
\hline Proyek rumah 2 lantai Pesanggrahan & 525.06 & 28.22 & 32.93 \\
\hline
\end{tabular}

Tabel 2 Material Pesanan

\begin{tabular}{cccc}
\hline Nama Proyek & \multicolumn{3}{c}{ Material Pesanan } \\
\cline { 2 - 4 } & $\begin{array}{c}\text { Semen } \\
(\mathrm{sak})\end{array}$ & $\begin{array}{c}\text { Pasir } \\
\left(\mathrm{m}^{3}\right)\end{array}$ & $\begin{array}{c}\text { Kerikil } \\
\left(\mathrm{m}^{3}\right)\end{array}$ \\
\hline Proyek Town House Sinar Indah 1 & 790 & 77 & 117 \\
\hline Proyek Town House Sinar Indah 2 & 859 & 83 & 127 \\
\hline Proyek Town House Sinar Indah 3 & 1267 & 124 & 61 \\
\hline Proyek Rumah Cluster 2 lantai Type Azela & 968 & 52 & 55 \\
\hline Proyek Pembangunan Ruko Bintaro & 374 & 36 & 78 \\
\hline Proyek Ruko 3 lantai Karang Tengah & 524 & 51 & 41 \\
\hline Proyek Rumah tinggal 2 lantai Rekayon Indah & 833 & 35 & 61 \\
\hline Proyek Rumah tinggal 2 lantai Cisauk & 983 & 52 & 49 \\
\hline Proyek Pembanguna rumah tinggal 2 lantai Sunter & 823 & 42 & 36 \\
\hline Proyek rumah 2 lantai Pesanggrahan & 573 & 30 & \\
\hline
\end{tabular}


Setelah mengetahui kebutuhan material yang ada dan material pesanan yang ada. Setelah itu menghitung jalan perhitungan volume material siap pakai dilapangan dikurangi dengan volume material desain untuk mendapatkan hasil sisa material. Hasil yang diperoleh dapat dilihat pada tabel 3 dibawah ini.

Tabel 3 Sisa Material

\begin{tabular}{cccc}
\hline Nama Proyek & & Sisa Material \\
\cline { 2 - 4 } & $\begin{array}{c}\text { Semen } \\
(\text { sak })\end{array}$ & $\begin{array}{c}\text { Pasir } \\
\left(\mathrm{m}^{3}\right)\end{array}$ & $\begin{array}{c}\text { Kerikil } \\
\left(\mathrm{m}^{3}\right)\end{array}$ \\
\hline Proyek Town House Sinar Indah 1 & 53.99 & 4.74 & 7.27 \\
\hline Proyek Town House Sinar Indah 2 & 49.39 & 3.51 & 6.29 \\
\hline Proyek Town House Sinar Indah 3 & 52.58 & 4.77 & 7.94 \\
\hline Proyek Rumah Cluster 2 lantai Type Azela & 75.40 & 4.02 & 5.02 \\
\hline Proyek Pembangunan Ruko Bintaro & 30.72 & 2.30 & 3.82 \\
\hline Proyek Ruko 3 lantai Karang Tengah & 39.63 & 3.44 & 5.78 \\
\hline Proyek Rumah tinggal 2 lantai Rekayon Indah & 68.89 & 2.50 & 3.10 \\
\hline Proyek Rumah tinggal 2 lantai Cisauk & 64.15 & 2.61 & 3.38 \\
\hline Proyek Pembanguna rumah tinggal 2 lantai Sunter & 61.75 & 2.80 & 3.23 \\
\hline Proyek rumah 2 lantai Pesanggrahan & 47.94 & 1.78 & 3.07 \\
\hline
\end{tabular}

Setelah melakukan perhitungan diatas maka didapatlah persentase sisa material dari masing-masing jenis material dan masing-masing proyek. Hasil perhitungan persentase dapat dilihat pada tabel 4.

Tabel 4 Persentase Sisa Material

Nama Proyek Persentase Sisa Material

\begin{tabular}{cccc} 
& $\begin{array}{c}\text { Semen } \\
(\%)\end{array}$ & $\begin{array}{c}\text { Pasir } \\
(\%)\end{array}$ & $\begin{array}{c}\text { Kerikil } \\
(\%)\end{array}$ \\
\hline Proyek Town House Sinar Indah 1 & 7.34 & 6.56 & 6.62 \\
\hline Proyek Town House Sinar Indah 2 & 6.10 & 4.42 & 5.21 \\
\hline Proyek Town House Sinar Indah 3 & 4.33 & 4.00 & 4.39 \\
\hline Proyek Rumah Cluster 2 lantai Type Azela & 8.45 & 8.38 & 8.97 \\
\hline Proyek Pembangunan Ruko Bintaro & 8.95 & 6.81 & 7.46 \\
\hline Proyek Ruko 3 lantai Karang Tengah & 8.18 & 7.24 & 8.01 \\
\hline Proyek Rumah tinggal 2 lantai Rekayon Indah & 9.02 & 7.68 & 8.17 \\
\hline Proyek Rumah tinggal 2 lantai Cisauk & 6.98 & 5.28 & 5.86 \\
\hline Proyek Pembanguna rumah tinggal 2 lantai Sunter & 8.11 & 7.16 & 7.05 \\
\hline Proyek rumah 2 lantai Pesanggrahan & 9.13 & 6.29 & 9.33
\end{tabular}


Setelah mendapatkan persentase masing-masing material pada masing-masing proyek dapat disimpulkan sebagai berikut pada tabel 5 .

Tabel 5 Rata-rata persentase sisa material

\begin{tabular}{lc}
\hline \multicolumn{1}{c}{ Material } & $\begin{array}{c}\text { Rata-rata persentase sisa material } \\
(\%)\end{array}$ \\
\hline Semen & 7.66 \\
\hline Pasir & 6.38 \\
\hline Kerikil & 7.11 \\
\hline
\end{tabular}

Pada tabel 5 dapat dilihat bahwa material semen memiliki persentase terbesar dengan nilai sebesar 7.66\%.

\section{Menentukan Kerugian dengan Regresi Linier}

Untuk mengetahui besarnya kerugian maka dilakukan perhitungan regresi linear dengan menggunakan software spss 22.0. Hasil perhitungan regresi linear. Maka hasil dapat dilihat pada tabel di bawah ini

\section{Coefficients $^{\mathrm{a}}$}

\begin{tabular}{|c|c|c|c|c|c|c|}
\hline \multirow{2}{*}{\multicolumn{2}{|c|}{ Model }} & \multicolumn{2}{|c|}{ Unstandardized Coefficients } & \multirow{2}{*}{$\begin{array}{c}\text { Standardized } \\
\text { Coefficients } \\
\text { Beta }\end{array}$} & \multirow[b]{2}{*}{$t$} & \multirow[b]{2}{*}{ Sig. } \\
\hline & & $B$ & Std. Error & & & \\
\hline \multirow[t]{4}{*}{1} & (Constant) & -1.640 & 1.303 & & -1.259 & .255 \\
\hline & Semen $(X 1)$ & .669 & .359 & .503 & 1.862 & .112 \\
\hline & Pasir (X2) & .481 & .244 & 410 & 1.970 & .096 \\
\hline & Kerikil $(X 3)$ & .098 & .213 & .100 & .461 & 661 \\
\hline
\end{tabular}

a. Dependent Variable: Kerugian $(M)$

Gambar 1. Hasil perhitungan regresi liniear dari program SPSS.

Artinya:

1. Berdasarkan tabel diatas maka dapat disimpulkan regresi liniernya adalah: $\mathrm{Y}=-1.640+0.669 \mathrm{X} 1+0.481$ $\mathrm{X} 2+0.098 \mathrm{X} 3$.

2. Nilai konstanta sebesar -1.640 menunjukan bahwa jika tidak ada variabel independen (semen, pasir, kerikil) maka variabel dependen (kerugian) adalah negative.

3. Nilai koefisien regresi X1 sebesar 0.669 artinya jika material dari variable X1 mengalami peningkatan, maka tingkat semen akan naik dengan asumsi variabel lain konstan.

4. Nilai Koefisien regresi X2 sebesar 0.481 artinya jika material dari variable X2 mengalami peningkatan, maka tingkat pasir akan naik dengan asumsi variabel lain konstan.

5. Nilai koefisien regresi X3 sebesar 0.098 artinya jika material dari variable X3 mengalami peningkatan, maka tingkat kerikil akan naik dengan asumsi variable lain konstan.

6. Standar error sebesar 3.682 artinya seluruh variabel yang dihitung dalam uji SPSS memiliki tingkat pengganggu sebesar 1.303 .

\section{KESIMPULAN DAN SARAN}


1. Kontribusi terbesar sisa material adalah material semen dengan persentase $7.66 \%$.

2. Model regresi persentase kerugian sebagai fungsi dari persentase material Waste dengan persamaan regresi dapat dihasilkan sebagai berikut: $\mathrm{Y}=-1.640+0.669 \mathrm{X} 1+0.481 \mathrm{X} 2+0.098 \mathrm{X} 3$

3. Faktor-faktor penyebab pada material waste yang dapat ditimbulkan dalam proyek sebagai berikut:

- Informasi gambar yang kurang mendetail sehingga menimbulkan kesalahan dalam desain.

- Kesalahan pemesanan, kelebihan, kekurangan, dan lain-lain dikarenakan terjadinya kesalahan komunikasi antara kontraktor dan pemasok.

- Pengukuran di lapangan tidak akurat sehingga terjadi kelebihan volume

- Kecerobohan dalam mencampur, mengolah dan kesalahan dalam penggunaan material disebabkan tenaga kerja yang kurang terampil dalam pekerjaan tersebut.

- Sisa material karena proses pemakaian

- Kehilangan akibat pencurian disebabkan oleh gudang penyimpanan material yang tidak dijaga ketat.

- Buruknya pengontrolan material di proyek dan perencanaan manajemen terhadap sisa material karena kurangnya pengawasan dan penanganan manajemen di proyek tersebut.

\section{DAFTAR PUSTAKA}

Bossink, B.A.G., H.J.H Browers. Construction waste: Quantification And Source Evaluation. Journal of Construction Engineering and Management. Vol.122. No.1 Maret 1996: 55-60

Gavilan, R.M., L.E Bernold. 1994. Source evaluation of solid waste in building construction. Journal of Construction Engineering and Management. Vol. 132 No.11. September 1994: 536 - 552

Illingworth, J.R. Waste in the construction process, 1998.

Intan, S. Analisa Dan Evaluasi Sisa Material Konstruksi: Sumber Penyebab, Kuantitas, Dan Biaya. Civil Engineering Dimension, Vol. 7. No.1 Maret 2005: 36 - 45

Skoyles, E.R., 1987, Waste Prevention On Site, Gread Britain: Butler \& Tanner Ltd. 1987: 18.

Waty, M., Gondokusumo, O., Sulistio, H, et al. Modeling of Waste Material Costs on Road Construction Projects International Journal of Engineering \& Technology, Vol. 7 No. 22018 474-477

Yayasan Lembaga Penyelidikan Masalah Bangunan, PBI 1971: Peraturan Beton Bertulang Indonesia. Bandung: Yayasan Lembaga Penyelidikan Masalah Bangunan, 1971 
